\title{
TELAAH KRITIS TERHADAP PANDANGAN C. PETER WAGNER TENTANG ROH-ROH TERITORIAL
}

\author{
Toni Irawan \\ Sekolah Tinggi Teologi Satyabhakti Malang \\ Irawan006@gmail.com
}

\begin{abstract}
This paper intends to criticize he views on territorial spirits developed by C. Peter Wagner. In his hypothesis he argued "the key for spreading the gospel is spiritual warfare, however, there is one sub-category of spiritual warfare that has great potential to accelerate world evangelization, namely the destruction of the power of territorial spirits Wagner's view of territorial spirits, although controversial in various fields, but it's actually accepted and practiced in certain churches in Indonesia. To examine this view, the author uses methodological library research which is classified as a type of qualitative research. This research found that Wagner was actually developing his ideas on the principle of "rejectionacceptance" which is loaded with pragmatism. Wagner's self-interest plays a very important role so that his view is his personal interpretation of the facts he presents. Wagner does not really allow facts to speak first, however, interprets facts first, so the results will definitely match his presumption. Finally, Wagner overly relates all matters to spiritual warfare, so that it causes him to tend to understand everything from the point of war. Wagner's view emphasizing only one side and ignoring the other sides finally made his theory lame.
\end{abstract}

Keywords: Critical studies; views of territorial spirits; spiritual warfare; the principle of refusal acceptance; accelerated evangelism.

\begin{abstract}
Abstrak
Tulisan ini bermaksud menelaah secara kritis pandangan tentang roh-roh teritorial yang dikembangkan oleh C. Peter Wagner. Dalam hipotesanya ia mengemukakan "kunci untuk keberhasilan pengabaran injil adalah peperangan rohani, tetapi ada satu sub-kategori dari peperangan rohani yang memiliki potensi besar untuk mempercepat penginjilan dunia, yaitu penghancuran kuasa roh-roh teritorial. Pandangan ini mengundang kontroversial tersendiri: di kubu tradisonal menganggap pandangan ini tidak Alkitabiah, tetapi di kalangan tertentu gereja-gereja pentakosta Kharismatik memahaminya sebagai pengajaran yang objektif. Pandangan Wagner tentang roh-roh teritorial meskipun kontroversial, namun faktanya justru diterima dan dipraktikan di gereja-gereja tertentu di Indonesia. Untuk menelaah pandangan ini, penulis menggunakan metode penelitian kepustakaan yang secara metodologis tergolong dalam jenis penelitian kualitatif. Dari penelitian ini didapati hasil telaah yang mengemukakan bahwa Wagner sebenarnya sedang mengembangkan gagasannya di atas prinsip "penolakanpenerimaan yang sarat dengan pragmatisme. Self interest Wagner sangat berperan sehingga pandangannya adalah penafsiran pribadinya terhadap fakta yang dipaparkannya. Wagner tidak benar-benar mengijinkan fakta berbicara terlebih dahulu, namun, menafsirkan fakta terlebih
\end{abstract}


dahulu, sehingga hasilnya pasti akan cocok dengan praduganya. Terakhir, Wagner berlebihan mengkaitkan semua persoalan dengan peperangan rohani, sehingga mengakibatkan ia cenderung memahami semua hal dari sudut peperangan. Pandangan Wagner yang menekankan hanya pada satu sisi dan mengabaikan sisi lain akhirnya membuat teorinya timpang

Kata Kunci: Telaah kritis; Pandangan roh-roh Teritorial; peperangan Rohani; prinsip penolakan penerimaan; Percepatan pengabaran injil

\section{PENDAHULUAN}

Suatu gelombang minat diskusi terhadap posisi-posisi Kristen berkaitan dengan peperangan rohani telah berkembang selama beberapa tahun ini. ${ }^{1}$ Topik tersebut yang sebelumnya dinilai mencerminkan pandangan dunia "primitif-prailmiah" dan cenderung menyebabkan ketidakseimbangan dalam berteologi, tetapi kini justru diadopsi dan dikembangkan menjadi strartegi baru dalam bidang studi pertumbuhan gereja. ${ }^{2}$ Chuck Lowe mengungkap perubahan wacana tersebut demikian,

"For Several decades-perhaps even a century or more-church leaders have been preoccupied with concrete measures designed to increase effectiveness in Ministry: techniques such as emotive hymns prolonged altar calls, bigger parking lots, homogeneous units, management principles, personality assessments and marketing techniques. Now there is scant time for such mundane matters, as Christians turn to the unseen battles of darkness and light, good and evil, heaven and hell., 3

Salah seorang berpengaruh dalam bidang studi perkembangan gereja yang tertarik mengembangkan pemikiran tersebut adalah C. Peter Wagner. ${ }^{4}$ Ia memahami bahwa dimensi rohani (peperangan rohani) sebenarnya menjadi kunci efektivitas penginjilan. ${ }^{5}$ Strategi penginjilan yang memperhitungkan tingkat penolakan yang dilakukan dalam dimensi rohani akan membawa efektifitas dalam pengijilan. Boleh dikatakan bahwa apabila kita dapat menghancurkan kekuasaan mereka melalui kuasa Allah, maka tingkat "penolakanpenerimaan" itu dapat langsung berubah dalam sekejap. Wagner mengemukakan bahwa kunci untuk menyebarkan Injil adalah peperangan rohani, tetapi ada satu sub-kategori dari

\footnotetext{
${ }^{1}$ Buku-buku seperti Frank Peretti telah menggugah masyarakat pembaca tertentu, sementara buku-buku karya penulis lainnya seperti Walker Wink telah menggerakan masyarakat pembaca lainnya. "Prestasi-prestasi baru" dipelopori oleh Larry Lea dan konferensi-konferensi peperangan dipelopori oleh John Wimber menarik perhatian ribuan umat Kristen. Sejumlah seminari teologi kini sedang memperkenalkan kursus-kursus kerohanian,, kuasa kesembuhan dan kelepasan. C Peter Wagner, Doa Peperangan: Strategi Untuk Bertempur Melawan Penguasa Kegelapan (Jakarta: Metanoia, 1994), 9.

${ }^{2}$ Ferry Setiawan Budi, "Meningkatkan Pertumbuhan Gereja Melalui Penerapan Strategi Peperangan Rohani," REDOMINATE: Jurnal Teologi dan Pendidikan Kristiani 1, no. 1 (December 2019): 50.

10.

${ }^{3}$ Chuck Lowe, Territorial Spirits and World Evangelisation? (Great Britain: OMF International, 2000),

${ }^{4}$ C. Peter Wagner pernah menjadi dosen di Donald A. McGavran, jurusan Pertumbuhan Gereja di Seminari Teologi Fuller, Pasadenawa,California. Sebelum datang ke Fuller pada tahun 1971, Wagner melayani sebagai utusan Injil di Bolivia selama 16 tahun. Ia adalah penulis lebih dari 30 buku tentang misi dan Pertumbuhan gereja. C Peter Wagner and F Douglas Pennover, Adu Kuasa Dengan Penghulu Kegelapan (Bandung: Yayasan Kalam Hidup, 1990), 69.

${ }^{5}$ C Peter Wagner, Roh-Roh Teritorial: Wawasan Terhadap Tingkat Strategis Peperangan Rohani Dari Sembilan Belas Pemimpin Kristen (Jakarta: Immanuel, 1994), 47.
} 
peperangan rohani yang memiliki potensi besar untuk mempercepat penginjilan dunia, yaitu penghancuran kuasa roh-roh territorial." 6

Pengaruh padangan Roh-roh territorial versi Wagner ini begitu meluas; tidak hanya mengisi kasanah teologi dengan kontroversi, tetapi juga memunculkan praktik-praktik baru dalam kegiatan bermisi. Lowe dengan gamblang menyuguhkan fakta tersebut demikian,

"...This new methodology has captured the popular imagination and is making considerable inroads into missionary thinking and stategy. The results are extradionary. A new-found enthusiasm for prayer has swept many churchs. Large numbers of mission teams travel on brief but costly trips into remote countries in order to challenge the spiritual forces of darknes in combative prayer. Books are written by the dozen, seminars held around the world, study groups formed, marches scheduled, all with one purpose: to disarm the spiritual powers of wickedness that impede the spread of the gospel.",

Sejumlah keberatan pada gilirannya muncul menyikapi pandangan ini: "Apabila dalil yang ditawarkan oleh pandangan ini benar, bukankah hal ini berarti bahwa misi tidak perlu lagi harus bergumul dengan persoalan adat, bahasa atau tantangan di suatu wilayah baru?" Makalah ini akan menyoroti secara kritis pandangan roh-roh teritorial menurut Wagner. Usaha kritis ini akan ditempuh dalam beberapa langkah, yang meliputi: paparan memadai mengenai konsep roh-roh terorial: latar belakang pemikiran, hipotesa, landasan Alkitabiah dan implikasinya. Konsep tersebut kemudian akan diuji dalam beberapa hal, yang meliputi: telaah terhadap hipotesa, metodologi interpretasi data, dan metode eksegesis yang digunakan Wagner dalam membangun teorinya. Pada akhirnya makalah akan diakhiri dengan proposal mengenai cara menyigkapi pandangan roh-roh tertorial secara bertanggungjawab.

\section{METODE PENELITIAN}

Dalam penelitian ini, penulis menggunakan metode penelitian kepustakaan. Secara metodologis, penelitian kepustakaan tergolong dalam jenis penelitian kualitatif. ${ }^{8}$ Dalam konteks penelitian kepustakaan, maka data-data diambil dari eksplorasi bahan-bahan pustaka dikaji secara holistik, kemudian dianalisis berdasarkan kerangka berpikir atau teori tertentu/paradigma filosofis yang melandasainya, selanjutnya menggunakan pendekatan tertentu sesuai tujuan penelitian yang ingin dicapai. ${ }^{9}$ Adapun jenis penelitian kepustakaan dalam makalah ini adalah penelitian kepustakaan: kajian pemikiran tokoh. Penelitian tentang pemikiran tokoh adalah usaha menggali pemikiran tokoh-tokoh tertentu yang memiliki karyakarya fenomenal. Karya-karya tersebut bisa berbentuk buku, surat, pesan atau dokumen lain

\footnotetext{
${ }^{6}$ Ibid.

${ }^{7}$ Lowe, Territorial Spirits and World Evangelisation?, 11

${ }^{8}$ Amir Hamzah, Metode Penelitian Kepustakaan: Kajian Filosofis, Teoritis, Dan Aplikatif (Batu: Literasi Nusantara, 2018) 25.

${ }^{9}$ Ibid.
} 
yang menjadi refleksi pemikirannya. ${ }^{10}$ Karya pemikiran tokoh yang diteliti dalam makalah ini adalah pemikiran C. Peter Wagner tentang "roh-roh teritorial."

\section{PEMBAHASAN DAN HASIL}

\section{Diskripsi Pandangan Roh-roh Teritorial oleh Wagner}

Dasar pandangan demonologi Wagner tentang roh-roh teritorial dimulai dari suatu hipotesa bahwa Iblis mengutus anggota-anggota pasukan roh jahatnya yang terkemuka untuk menguasai bangsa, kawasan, kota, suku, kelompok, daerah tertentu, dan jaringan sosial lainnya di dunia ini. Secara eksplisit Wagner mengemukakan hipotesa kerjanya tersebut demikian,

"Jadi hipotesa yang ingin saya sodorkan adalah sama dengan yang saya kutip dari Timothy Warner, yaitu bahwa iblis mengutus anggota-anggota pasukan roh jahatnya yang terkemuka untuk menguasai bangsa-bangsa, kawasan-kawasan, kota-kota, sukusuku, kelompok-kelompok, daerah-daerah tertentu, dan jaringan-jaringan sosial lainnya di dunia. Tugas mereka adalah menghalangi agar Allah tidak dimuliakan di daerah mereka, dan hal ini mereka laukan dengan perantaraan rohh-roh jahat lebih rendah kedudukannya." 11

Bagaimana memahami secara utuh hipotesa kerja Wagner ini secara utuh? Wagner menempatkan pemberitaan Injil selalu dalam konteks "konflik adu kuasa" dengan roh jahat. Orang-orang yang terlibat dalam penginjilan harus menyadari bahwa dirinya diutus untuk berperang melawan kekuatan kerajaan kegelapan. Dengan demikian, mereka tidak seharusnya menghindari konflik adu kuasa kuasa dengan roh jahat. Namun sebaliknya, hal itu harus disikapi sebagai pintu efektif pemberitaan Injil. Wagner menjelaskan gagasan tersebut demikian,

"Kita dengan sadar berhadapan dengan kerajaan iblis setiap hari. Dalam situasi inilah kita perlu memanfaatkan otoritas Kristus, sebagaimana yang dinyatakan dalam amanat agung, untuk menyembuhkan penyakit dan mengusir setan, mendemonstrasikan pemerintahan Allah. Konflik-konflik ini disebut adu kuasa, yakni berbenturnya kerajaan Allah dengan kerajaan Iblis. Hal ini dapat terjadi dalam berbagai situasi, pengusiran roh-roh jahat merupakan bentuk yang paling dramatis beradunya kuasa itu bukan hanya terbatas pada hal-hal yang menyangkut roh-roh jahat. Ketika orang-orang yang tidak percaya mengalami beradunya kuasa atau menyaksikan peristiwa seperti itu, mereka terbawa pada suatu tingkat kesadaran yang baru dalam mengambil keputusan dan bagi Kristus. Allah itu hadir dan mereka mengetahuinya. Beradunya kuasa ini merupakan pintu masuk kedalam kerajaan Allah".12

Di satu sisi, Wagner menegaskan bahwa kuasa yang dimiliki roh jahat memang tidak dapat di remehkan begitu saja. Namun meskipun demikian, Iblis sebenarnya tidak memiliki sifat-sifat yang dimiliki Allah, dan oleh karena itu tidak bersifat maha hadir. Walaupun iblis dapat

\footnotetext{
${ }^{10}$ Amir Hamzah, Metode Penelitian Kualitatif: Rekontruksi Pemikiran Dasar Serta Contoh Penerapan Pada Ilmu Pendidikan, Sosial Dan Humaniora (Batu: Literasi Nusantara, 2018), 269.

${ }^{11}$ Wagner and Pennover, Adu Kuasa Dengan Penghulu Kegelapan, 72.

12 Wagner, Roh-Roh Teritorial: Wawasan Terhadap Tingkat Strategis Peperangan Rohani Dari Sembilan Belas Pemimpin Kristen, 47.
} 
berpindah-pindah dari satu tempat ke tempat yang lain dengan cepat, namun iblis hanya berada di satu tempat pada waktu tertentu. ${ }^{13}$ Jelas, iblis harus mendelegasikan tanggung jawab untuk membutakan pikiran manusia kepada makhluk-makhluk roh yang tidak terhitung bayaknya, yaitu roh-roh jahat yang tunduk kepadanya. ${ }^{14}$ Dengan demikian, masuk akal jika dikatakan bahwa semakin banyak orang yang harus dibutakan, tentu semakin besar pula jumlah dari roh-roh jahat yang harus diutus olehnya. Iblis mengutus anggota-anggota pasukan roh jahatnya yang terkemuka untuk menguasai bangsa-bangsa, kawasan-kawasan, kota-kota, dan suku-suku, daerah-daerah tertentu, dan jaringan-jaringan sosial lainnya. ${ }^{15}$ Tugas mereka adalah menghalangi agar manusia tidak memuliakan Allah di daerah mereka, dan hal-hal ini mereka lakukan dengan perantaraan roh-roh jahat yang lebih rendah kedudukannya.

Pemberita Injil yang menginginkan hasil yang efektif harus memperhitungkan dengan cermat keberadaan penguasa-penguasa teritorial. Apabila mereka mampu mengenali dan mengidentifikasi secara rinci keberadaan roh-roh yang menguasai teritorial tertentu, maka mereka akan mampu mengidentifikasi seberapa besar kekuasatan roh-roh jahat tersebut dan menaklukannya dengan mudah. Para pemberita injil yang dapat menghancurkan kekuasaan roh teritorial melalui kuasa Allah, maka akan melihat tingkat penolakan-penerimaan dapat langsung berubah dalam sekejap. Beberapa contoh peristiwa tersebut, dia tuliskan dalam dua buku yang berjudul The Third wave of the Holy Spirit dan How to Have a Healing Minsitry. Secara singkat paparan mengenai contoh peristiwa-peristiwa tersebut, meliputi:

"Di Thailand: Gelombang pertobatan langsung terjadi ketika para utusan Injil menyisihkan sehari dalam seminggu untuk peperangan rohani. Di Costa Rica: gejalagejala sakit jiwa lenyap setelah seorang pasien mengadakan perjalanan ke Amerika serikat, tetapi kambuh kembali ketika ia kembali ke Costa Rica. Seorang psikolog Kristen bernama Rita Cabezas diberitahu oleh salah satu roh jahat bahwa roh teritorial mereka terbatas hanya di Costa Rica saja. Di Filipina: Lester Sumrall mengusir roh yang memasuki seorang narapidana di penjara Bilibid. Akibatnya banyak orang-orang Filipina membuka hati untuk pemberitaan Injil. Di Argentina: Omar Cabrera, melalui doa dan puasa, mengadakan pelayanan khusus di bidang pengenalan roh-roh jahat. Di Korea: Paul Yonggi Cho menghubungkan perbedaan tingkat penerimaan Injil antara Jerman dan Korea kepada kemenangan-kemenangan dalam peperangan rohani yang tercapai melalui pelayanan doa peperangan rohani. Di Argentina: Edgardo Silvoso melaporkan tentang pertumbuhan gereja yang berlipat ganda dalam radius 100 mil dari kota Rosario setelah tim menghancurkan kuasa-kuasa Roh yang menguasai Merigildo pada tahun $1985 .^{16}$

Wagner kemudian membangun konsep roh-roh teritorial di atas penafsiran beberapa ayat Alkitab yang dianggap sahih mendukung teorinya. Langkah pertama ialah dengan membangun argumentasi di atas pernyataan Paulus dalam Efesus 6:12, “perjuangan kita

\footnotetext{
${ }^{13}$ Wagner and Pennover, Adu Kuasa Dengan Penghulu Kegelapan, 71.

${ }^{14}$ Ibid.

${ }^{15}$ Ibid, 48.

${ }^{16}$ Ibid, 76-77.
} 
bukanlah melawan darah dan daging, tetapi melawan penghulu-penghulu dunia yang gelap ini, melawan roh-roh jahat di udara." Wagner memahami bahwa ayat-ayat tersebut secara jelas menujukkan bahwa peperangan rohani tingkat tinggi melawan roh-roh territorial adalah suatu realita, bahkan suatu medan konflik yang harus dihadapi para pemberita Injil. ${ }^{17}$ Pemberitaan Injil itu sendiri harus dipahami sebagai suatu perjuangan, dimana para pemberita injil tidak seharusnya bediam diri, namun sebaliknya justru mengambil tindakan untuk menggempur kubu roh-roh teritorial. ${ }^{18}$

Lebih lanjut, Wagner kemudian menunjukkan bahwa Yesus dalam pelayanannya juga terlibat aktif dalam peperangan rohani tingkat tinggi. Bagi Wagner teks Matius 12:19, tentang penjelasan Yesus mengenai kedatangan kerajaan Allah, jelas menunjuk kepada pengikatan orang yang kuat (Mat. 12:19). Wagner tidak meragukan lagi bahwa orang kuat yang dimaksud oleh Yesus tidak lain adalah roh-roh jahat itu sendiri, "Tetapi jika Aku mengusir setan dengan kuasa Roh Allah, maka sesungguhnya kerajaan Allah sudah datang kepadamu” (Mat. 12:28). ${ }^{19}$ Dalam teks tersebut, kata "rumah" juga harus dimengerti sebagai gambaran teritorial yang dikuasai oleh Iblis atau pesuruh-pesuruhnya, dan territorial itu tak dapat diambil alih apabila orang kuat yang menguasai rumah tersebut belum diikat. ${ }^{20}$ Namun apabila roh-roh territorial tersebut dapat ditundukkan maka Kerajaan Allah dapat memasuki kawasan itu.

Selanjutnya Wagner juga mengangkat peristiwa pertemuan antar Paulus dengan Elimas (Kis. 13:4-12), sebagai peristiwa khusus mengenai penghancuran kuasa roh-roh teritorial. Ketika Paulus berhadapan dengan tukang tenung di Siprus Timur tersebut, ia sebenarnya tengah berhadapan dengan representatif penguasa teritorial di wilayah itu. ${ }^{21}$ Hubungan Elimas yang akrab dengan kepala pemerintahan wilayah itu, yakni proconsul Sergius Paulus, membuktikan kekuasaan roh atas wilayah itu. Walaupun penguasa itu tidak disebutkan namanya, namun ketika terjadi adu kuasa yang akhirnya menghancurkan kuasa Elimas (yang disebut "anak Iblis"), maka proconsul itu akhirnya menjadi percaya.

Wagner juga menduga bahwa gagasan tentang roh-roh jahat yang menguasai suatu teritorial tertentu muncul berulang kali dalam Perjanjian Lama. Pertama, ia mengangkat nyanyian Musa dalam Ulangan 32:8 terjemahan Septuaginta: "Ketika yang mahatinggi membagi-bagikan milik pusaka kepada bangsa-bangsa, ketika Ia memisah-misah anak-anak manusia, maka Ia menetapkan wilayah bangsa-bangsa menurut bilangan malaikat-malaikat Allah.” Penguasa malaikat tersebut digambarkan sebagai penghulu-penghulu, kuasa-kuasa musuh yang jahat" penguasa-penguasa dunia yang gelap" seperti yang disebutkan dalam

\footnotetext{
${ }^{17}$ Ibid, 73.

${ }^{18}$ Ibid.

19 Ibid.

${ }^{20}$ Ibid.

${ }^{21}$ Ibid, 74.
} 
Efesus 6: 12."22 Keberadaan roh-roh teritorial yang tersirat dalam Ulangan 32: 8 itu, tergungkap jelas dalam kitab Daniel; di mana tiga pemimpin yakni pemimpin dari Persia dan pemimpin dari Yunani, dan satu pihak yang baik, yaitu Mikhael yang disebut salah satu pemimpin yang terkemuka. ${ }^{23}$ Di dalam cerita itu selanjutnya dikatakan, satu malaikat yang diutus Tuhan untuk melayani Daniel berperang melawan pemimpin dari Persia selama 21 hari dan ia tak dapat mengalahkannya sampai Mikhael datang untuk membantunya.

Roh-roh teritorial dan kekuasaan mereka atas wilayah-wilayah geografis tertentu, dalam sejarah Israel, sering dianggap remeh. ${ }^{24}$ Yosua menegur umat Israel karena mereka beribadah kepada Ilah-ilah seberang sungai dan di Mesir (Yos. 24: 14). Bahkan di Kanaan, umat Israel tidak menyucikan tanah itu sebagaimana diperintahkan Allah, melainkan sebaliknya mereka "melupakan Tuhan Allah mereka, dan beribadah kepada Baal dan Asyera : (Hak. 3: 7). Beberapa dari nama-nama penguasa tertentu disebutkan, seperti Sukot Bebot dari Babel, Nergal dari Kuta, asima dari Hamat, Nibhas dan Tartak dari Arwa, dan Adramelekh dari Sefarwaim (2 Raj. 17: 30-31). Kuasa okultisme dari penguasa-penguasa ini dikaitkan dengan ayat-ayat sebelumnya di dalam pasal ini yang menyebutkan mengenai perbuatan tenung (2 Raj. 17: 17). Yeremia menyebutkan tentang kejatuhan Babel dengan kalimat-kalimat "Babel telah direbut" dan "merodakh telah terkejut dan berhala-berhalanya telah menjadi malu" (Yer. 50: 2).

\section{Implikasinya dalam Praktik Peperangan Rohani}

Gagasan roh-roh teritorial yang dikembangkan Wagner pada akhirnya memiliki implikasi yang luas terhadap praktik peperangan rohani. Praktik awal peperangan rohani yang biasa dilakukan oleh orang-orang yang telah memahami keberadaan roh-roh teritorial ialah menemukan nama-nama roh-roh jahat secara khusus dan melawannya secara pribadi. ${ }^{25}$ Wagner beranggapan bahwa apabila kita tahu musuh kita secara detail, maka dengan mudah kita masuk ke dalam peperangan rohani dan menetapkan sasaran doa. Usaha ini dapat ditempuh dengan cara melakukan pemetaan rohani terhadap setiap wilayah yang menjadi target. ${ }^{26}$ Dalam metode pemetaan rohani, para pendoa akan mengidentifikasi indentitas rohroh teritorial dengan melihat kecendrungan pengaruh roh-roh tersebut terhadap situasi sejarah, budaya,dan kebiasaaan sosial masyarakat setempat. Dengan cara tersebut maka mereka dapat

22 Ibid.

23 Ibid.

${ }^{24}$ Ibid, 75.

${ }^{25}$ Wagner meneguhkan praktek ini dengan menyodorkan ayat-ayat dalam Matius 5: 9 sebagai bukti eksplisit. Ketika Yesus melayani orang Gadara yang dirasuk setan, Yesus bertanya tentang nama roh itu dan mendapati bahwa namanya Legion. Apabila hal seperti ini sering digunakan terhadap orang-orang yang terserang roh-roh jahat, kemungkinan hal inji dapat dilakukan terhadap roh-roh teritorial. Ibid, 79.

${ }^{26}$ Wagner, Doa Peperangan: Strategi Untuk Bertempur Melawan Penguasa Kegelapan, 168. 
menyingkapakan pengaruh setan dan kerajaannya, dan sekaligus menyediakan data-data intelijen bagi peperangan rohani. ${ }^{27}$

Bagian integral dari strategi untuk memerangi roh-roh teritorial berikutnya adalah berurusan dengan dosa korporat dari sebuah kota atau daerah. ${ }^{28}$ Diasumsikan bahwa kelakuan berdosa masayarakat setempat telah membuka jalan bagi para penghulu dan penguasapenguasa territorial di udara. Roh-roh tersebut akan membangun benteng-benteng di suatu bangsa atau suatu kota, mempengaruhi masyarakat pada umumnya dan menolak injil khususnya. Kubu-kubu tersebut tidak akan bisa dihancurkan terkecuali melalui tindakan merendahkan diri dan bertobat secara korporat.

Sesudah mengenali nama-nama penguasa gelap dari sebuah kota, mengaku dan berdoa dosa pertobatan, maka langkah terakhir adalah terlibat dalam doa peperangan agresif menyerang roh-roh teritorial. Wagner secara umum membagi doa peperangan agresif dalam tiga tingkat: peperangan rohani tingkat dasar (permukaan), peperangan rohani tingkat okultisme, dan peperangan rohani tingkat strategis. Dalam peperangan rohani tingkat dasar (permukaan), seseorang tengah terlibat dalam konfrontasi terhadap roh-roh jahat yang sering menyerang atau mengganggu orang secara perorangan. Kelompok-kelopmpok dan individuindividu yang terlibat dalam "pelayanan-pelayanan kelepasan" secara sepenuh terjun dalam peperangan rohani tingkat dasar ini. ${ }^{29}$ Pada level kedua, peperangan rohani tingkat okultisme, tampak jelas seseorang akan melihat sejenis kuasa roh jahat sedang bekerja melalui pelaku okultisme, dukun, para pendeta sesat, peramal nasib dan sejenisnya. Di level ini, pada pokoknya berbeda dengan roh jahat biasa yang biasa menyebabkan sakit-penyakit atau hancurnya perkawinan. Peperangan rohani pada tingkat okultisme dimaksudkan untuk membeberkan dan membongkar pekerjaan yang dilakukan kuasa gelap secara terorganisir. Di level paling atas, yaitu peperangan rohani tingkat stategis, seseorang tengah bergumul melawan pusat kekuatan roh jahat yang jauh lebih besar, mereka berhadapan dengan "pemerintah-pemerintah" dan penguasa kegelapan di alam roh, seperti digambarkan oleh rasul Paulus dalam Efesus 6:12

${ }^{27}$ Ibid.

${ }^{28}$ Data Perjanjian Lama memamparkan bahwas bangsa-bangsa dapat menjadi jahat karena dosa-dosa bersama. Hal ini bkukan hanya benar dalam bangsa-bangsa kafir, tetapi juga Israel. Baik Nehemia maupun Danil member kita contoh-contoh sejumlah orang benar yang merasa berbeban karena dosa-dosa mereka. Mendengar bahwa tembok Yerusalem runtuh dan gerbang-gerbanya terbakar, Nehemia menangis, berpuasa dan berdoa. Ia mengakui berbagai dosa anak-anak Israel pada umumnya, berupaya untuk menghapus dosa-dosa seluruh bangsa. Ia berkat, juga aku dan kaum keluargaku telah berbuat dosa (Neh. 1: 6). Daniel, melalui bacaan Alkitab, dapat menyadari bahwa masa pembuangan Israel selama 70 tahun akan segera berakhir. Oleh sebab itu, ia pergi menghampiri Tuhan dalam "doa dan permohonan, dengan puasa, kain sarung, dan abu" 9dfan. 9: 3). IA mengakui dosa-dosa bangsanya dengan menyebutkan secara rinci, "segenap orang Israel telah melanggar hukumMu dan menyimpang karena tidak mendegar suaraMu (Dan. 9: 11). Ibid, 144.

${ }^{29}$ C Peter Wagner, Berdoa Dengan Penuh Kuasa: Cara-Cara Berdoa Yang Efektif Dan Mendengar Suara Tuhan Dengan Jelas (Jakarta: Nafiri Gabriel, 1997), 78-79. 


\section{Penilaian Kritis Terhadap Pandangan Roh-roh Teritorial Wagner \\ Apakah Hipotesa Roh-roh Teritorial Sahih?}

Riset Wagner dalam studi pertumbuhan gereja dan pengalaman pelayanannya sebagai utusan Injil di Bolivia selama 16 tahun, pada akhirnya menuntun dia untuk mengkaji ulang faktor-faktor yang mempengaruhi pertumbuhan gereja. Ia kemudian tiba pada suatu asumsi bahwa terdapat dimensi rohani yang mempengaruhi efektifitas pemberitaan injil. Pemberitaan Injil dalam faktanya tengah berhadapan dengan kuasa roh-roh jahat: pada saat Injil diberitakan, pada kesempatan yang sama Iblis tengah bekerja membutakan orang untuk menerimanya. Dengan demikian, pemberitaan Injil itu tidak hanya bersangkutan dengan masalah komunikasi lintas budaya. Lebih daripada itu pemberitaan Injil sebenarnya adalah peperangan rohani; adu kuasa melawan roh-roh jahat. Dengan demikian, apabila pemberita Injil dapat menemukan faktor-faktor apa yang menjadi penghambat dan menghancurkannya, maka tingkat penolakan akan berubah dalam waktu sekejap. ${ }^{30}$

Sesudah mengenali roh-roh territorial yang menghambat penginjilan sebuah kota, mengaku dan berdoa dosa pertobatan, maka langkah terakhir yang ditawarkan oleh Wagner adalah terlibat dalam doa peperangan agresif menyerang roh-roh teritorial. Wagner secara umum membagi doa peperangan agresif dalam tiga tingkat: peperangan rohani tingkat dasar (permukaan), peperangan rohani tingkat okultisme, dan peperangan rohani tingkat strategis (DPRTS). Menurutnya, doa peperangan tingkat strategis seharusnya menjadi prioritas utama dari umat Tuhan karena doa ini memiliki efektifitas yang tinggi dalam kaitan dengan kegiatan penginjilan. ${ }^{31}$ Mengapa bisa demikian? Karena doa ini difokuskan untuk menggempur kekuatan yang berada di balik setiap pemberontakan terhadap Allah dan penolakan terhadap pemberitaan Injil.

Apabila mencermati gagasan roh-roh teritorial versi Wagner ini, bisa ditemukan bahwa prinsip "risiko besar, untung besar" tidak hanya berlaku dalam dunia bisnis, namun juga dalam hal doa peperangan rohani tingkat strategis versi Wagner. ${ }^{32}$ Di sini kita menemukan bahwa gagasan roh-roh teritorial Wagner sarat dengan pragmatisme. Metodologi pragmatis selalu menitik beratkan pada pencapaian hasil semata, dan mengukur setiap pengetahuan dari sudut kegunaan praktisnya. Sahihkah pendekatan ini untuk menguji kebenaran? Norman Geisler, memberikan awasan bahwa pendekatan ini memiliki beberapa kelemahan mendasar. Pertama, hasil atau akibat dari tindakan sebenarnya tidak dapat membuktikan apakah hal itu benar, tetapi semata-mata hanya menunjukkan apa yang dikerjakan. ${ }^{33}$ Kedua, kebenaran tidak harus

\footnotetext{
${ }^{30}$ Wagner and Pennover, Adu Kuasa Dengan Penghulu Kegelapan, 71.

${ }^{31}$ Soerono, "Telaah Kritis Terhadap Konsep Doa Peperangan Rohani Tingkat Strategis Menurut Peter Wagner,”Veritas: Jurnal Teologi dan Pelayanan 7, no. 1 (2006): 102.

32 Ibid.

${ }^{33}$ Norman Geisler, Christian Apologetics (Grand Rapids Michigan: Baker Book House, 1976), 113.
} 
selalu dihubungkan dengan hasil. ${ }^{34}$ Wagner menguji dan mengesahkan hipotesanya lantaran dia mengamati hasil-hasil atau fakta di lapangan nampaknya mencerminkan hasil hipotesanya. Di sinilah kita mendapati bahwa self interest Wagner sangat berperan; lebih sederhananya teori Wagner sebenarnya tidak lebih dari sekedar penafsiran pribadinya terhadapa fakta yang ia dipaparkan.

\section{Bagaimana dengan Metode Interpretasi Data Wagner?}

Bagi Wagner pemberitaan Injil akan berujung pada kegagalan seperti yang dialami oleh misonaris-misonaris tertentu, apabila hanya datang mengandalkan teologi dan pemahaman komunikasi lintas budaya, namun tidak menggubris adanya adu kuasa dengan penguasa roh-roh jahat. Guna mendukung gagasannya Wagner kemudian menyajikan beberapa peristiwa masa kini yang dia rasa dapat mendukung kebenaran teorinya. Contohcontoh tersebut merupakan beberapa kisah yang cukup menarik dan fantastis. Mungkin dengan mengangkat beberapa kisah yang terjadi di beberapa tempat, Wagner berharap akan mampu menyakinkan para pembacanya.

Wagner dalam tahap tertentu berusaha melengkapi teorinya dengan beberapa peristiwa di lapangan. Namun, pada saat yang sama, ia terburu-buru untuk mengesahkan peristiwa tersebut sebagai fakta yang terkait langsung dengan hasil peperangan rohani. Apakah peristiwa-peristiwa tersebut merupakan fakta yang berkorelasi dengan peperangan rohani? Dalam hal ini, Wagner tidak berusaha menyuguhkan pembuktian yang memadai, tetapi ia hanya bergantung kepada opini pribadi orang-orang yang terlibat dalam peristiwa tersebut. Ia menyakini bahwa pendapat-pendapat: Rita Cabezas, Lester Sumrall, Omar Cabrera, Yonggi Cho dan Edgardo Silvoso, sebagai dasar untuk mengesahkan peristiwa-peristiwa tersebut sebagai fakta yang terkait dengan peperangan rohani. ${ }^{35}$ Tanpa mendeskreditkan beberapa tokoh tersebut; tindakan mengangkat komentar-komentar mereka sebagai bahan pertimbangan utama dapat dinilai sebagai pernyataan teoritis yang tidak dapat dipertanggunjawabkan secara objektif. Pendapat-pendapat beberapa tokoh tersebuit seharusnya hanya dapat diterima sebagai opini pribadi, dan bila mengangkatnya sebagai pembuktian atas suatu fakta, maka tentunya memerlukan verifikasi secara ilmiah dan historis. Terhadap tindakan ini, Byron D. Klaus mengemukakan,

"Secara singkat, namun penting, pengamatan Dr. Wagner bahwa pemahaman yang seksama menjadi unsur yang sangat penting bagi gereja dan para pemimpinnya yang akan terjun masuk ke dalam penelitian topik yang sangat peka ini. Gambaran studistudi kasus yang telah dikemukakan membutuhkan lebih daripada sekedar penelitian

\footnotetext{
34 Ibid.

${ }^{35}$ Wagner, Roh-Roh Teritorial: Wawasan Terhadap Tingkat Strategis Peperangan Rohani Dari Sembilan Belas Pemimpin Kristen, 50.
} 
yang perlu keabsahan atas kebenarannya. Hal-hal ini memanggil kita untuk melangkah dengan kebulatan tekad, yakni penetapan kembali pelayanan-pelayanan yang berorientasi pada pengenalan roh-roh yang dibarengi dengan proses verifikasi yang sah dan dewasa. ${ }^{36}$

Dalam proses ilmiah asumsi pasti dibangun di awal, namun hal tersebut bila tidak diverifikasi secara logis maka akan cenderung membawa bangunan teori yang terkesan subjektif. Lebih tepatnya asumsi harus ditempatkan sebagai praduga yang harus diuji, sehingga hasil akhir akan memperlihatkan kebenaran asumsi tersebut. Namun, tindakan Wagner dalam mengangakat peristiwa-peristiwa di lapangan tersebut, telah cenderung ditafsir terlebih dahulu dari kaca mata asumsinya. Sederhananya, Wagner tidak benar-benar mengijinkan fakta berbicara terlebih dahulu. Namun, menafsirkan fakta terlebih dahulu, sehingga hasilnya pasti akan cocok dengan praduganya. Dengan demikian, kita dapat melihat bahwa metode interpretasi data wagner sebenarnya cenderung subjektif .

\section{Gagasan Roh-roh Teritorial Apakah Alkitabiah?}

Penafsiran merupakan usaha untuk menemukan maksud mula-mula daripada teks-teks yang tengah ditafsir. Proses penafsiran dapat digambarkan sebagai usaha menarik keluar arti sebenarnya dari teks-teks tersebut, sebalinya proses yang memasukan pemikiran penafsir kepada teks dinilai sebagai usaha eisogesis yang memanipulasi kebenaran teks. ${ }^{37}$ Selain riset historis dan studi kata, alat uji signifikan yang dipakai dalam penafsiran adalah menguji setiap teks dari konteksnya. Bagaimana dengan metodologi tafsir yang dikembangkan oleh Wagner dalam mendekati data-data Alkitab yang ia paparkan? Apakah konteks teks-teks seperti Daniel 10:10-21; 2 Raja-raja 17:30-31; dan Efesus 6:1 sebenarnya mengarah kepada pembahasan mengenai roh-roh teritorial?

Sebenarnya berbicara mengenai roh-roh teritorial, apakah teks dalam Daniel 10:10-21 berbicara tentang roh-roh teritorial? Ada tiga hal mendasar yang perlu dipertimbangkan dalam mencerna gagasan dalam teks Daniel 10: 10-21 tersebut. Pertama, konteks peristiwa tersebut sebenarnya tidak sedang menujuk pada tingakatan roh teritorial. Daniel tidak berminat untuk membahas hal tersebut, melainkan dia sedang prihatin terhadap nasib Israel yang sdang di tindas oleh imperium yang tidak taat kepada Allah. Bagi Daniel imperium tersebut merupakan representasi daripada setan. Lowe menjelaskan fakta ini demikian:

\footnotetext{
${ }^{36}$ Wagner and Pennover, Adu Kuasa Dengan Penghulu Kegelapan, 89.

${ }^{37}$ Hasan Sutanto, Hermeneutik: Prinsip Dan Metode Penafsiran Alkitab (Malang: SAAT, 2007) 3.
} 
"In any event, Daniel is not interested in structure of demonnic hierarchies. He is concerned with the fate of Israel, oppressed by world powers. His point is merely that any empire which attacks Israel is opposing God and serving satan. In that respect these powers are demonic. More than this he does not say. nor can we.",38

Kedua, apabila kita memperhatikan Daniel 12:1, secara eksplisit tertulis, "Pada waktu itu juga akan muncul Mikhael, pemimpin besar itu, yang akan mendampingi anak-anak bangsamu" Mikael disebutkan melindungi bangsa Israel, bukan teritorial. Apabila sebutan itu berlaku untuk Mikael, berarti sebutan tersebut juga berlaku untuk penguasa Persia dan Yunani. Hal ini menujukkan bahwa baik Mikael maupun penguasa Persia dan Yunani ditempatkan bukan sebagai penguasa dalam hirarkhi roh-roh tertentu. Sama sekali tidak ada indikasi mengarah kepada susunan seperti itu. Sebutan mereka sebagai penguasa yang melindungi bangsa mungkin lebih tepat ditengarahi sebagai representatif kekuatan ilahi yang sedang berkonfrontasi: kekauatan Allah versus setan. Collin mengobservasi demikian, " $a$ battle between two earthly powers is a reflectionh of a battle between their respective gods." Ketiga, yang harus dipikirkan menyangkut teritorial dalam dunia Daniel pada waktu itu. Apabila kita berbicara "teritorial" pada jaman imperium Persia dan Yunani, batas-batas teritorial tersebut sebenarnya tidak tetap karena mereka cenderung memperluas wilayahnya dengan menaklukkan wilayah-wilayah lain. Faktanya seperti berikut:

"The subsequent chapters in Daniel indicate that Persia and Greece not fixed geographical regions, nor were they co-operative world powers. Instead, they were successive and rival empires, comptetitors world dominion (Dan 11: 2-35). Within the time frame of the book of Daniel, the Babylonians conquered the Persians, but supplanted by the Persians. Subsequenly the Greek empire conquered the Persians, before splitting into four rival kingdoms, 40

Dengan demikian jelas, gagasan teritorial seperti yang dimaksudkan oleh Wagner sebenarnya tidak cocok dengan gagasan teritorial pad masa tersebut.

Bagaimana dengan nama-nama Dewa yang disebutkan dalam 2 Raja 17:30-32?. Kita harus membedakan apa yang dipercaya ada oleh orang dan apa yang benar-benar ada? SukotBenot, Nergal, Asima sebenarnya mencerminkan apa yang dipercaya ada dan disembah oleh orang-orang pada jaman itu, tetapi sebenarnya mereka tidak benar-benar ada. Lowe kembali mengupas dengan gamblang ayat-ayat ini:

"Turning to the actual biblical accounts, it happens that much of the data is misconstrued. Cultichigh places, for examples, are interpreted as "the literal dwelling place of demonic spirits. But the old testament consistenly describes these as "places ... where the nations worships ... their Gods" (Deut 12:2-3; cf. 2 King 17: 11; 23: 5; 2 2 Chr 28: 25). By my count there are eighty-six references to "high places" in the Old

\footnotetext{
${ }^{38}$ Lowe, Territorial Spirits and World Evangelisation?, 34.

39 Ibid.

${ }^{40}$ Ibid.
} 
Testaament, yet not one states or implies that the gods are actually located at the site or restricted to it, only that they are worshiped there. "41

Kisah lain yang hampir sama terdapat dalam Kisah Ahas,” Ia membakar juga korban di Lebak Ben-Hinom dan membakar anak-anaknya sebagai korban dalam api, sesuai dengan perbuatan keji bangsa-bangsa yang telah dihalaukan TUHAN dari depan orang Israel.” ( II Taw. 28:3). Ahas berspekulasi bahwa ia sedang menyembah dewa Kanaan karena dia mengasumsikan penguasa tersebut ada, padahal penguasa tersebut sebenarya hanya kepercayaan orang-orang Kanaan. Lebih lanjut, dalam Yesaya 44:8-20, terdapat puisi yang mengejek orang-orang yang membuat dewa-dewa mereka, yang bukan lain dari wujudi imajinasi mereka sendiri yang keliru. Yeremia 10:2-5, memperingatkan orang-orang Israel untuk tidak takut pada ilah-ilah yang lain, seperti yang dilakukan oleh bangsa-bangsa lain, sebab sesungguhnya mereka tidak benar-benar ada

Bagian Alkitab lain yang sering digunakan oleh Wagner adalah Efesus 6:10-18. Teks tersebut memang mengungkapkan keberadaan kuasa roh jahat sebagai lawan orang Kristen dalam peperangan rohani. Keberadaan roh-roh jahat tersebut meliputi: pemerintah-pemerintah, penguasa-penguasa, penghulu-penghulu dunia yang gelap ini, dan roh-roh jahat di udara. Namun penyebutan nama-nama tersebut tidak harus dimengerti sebagai suatu tingkatan atau penggolongan roh-roh tertentu. Minat Paulus dalam konteks tersebut bukanlah pada point tentang adanya tingkatan-tingakatan roh, namun yang menjadi minat pembahasan Paulus jusru pada substansi peperangan rohani itu sendiri. Dalam Efesus 6:11, pepeperangan yang dimaksudkan oleh Paulus bukanlah peperangan yang sifatnya menyerang (offensive), tetapi sebaliknya adalah peperangan yang sifatnya bertahan (defensive). Paulus mengisyaratkan dengan jelas bahwa kekuatan untuk bertahan tersebut hanya terjadi diperoleh apabila umat Kristen bergantung penuh pada kuasa Tuhan, (Ef. 6:10), yaitu dengan mengenakan seluruh perlengkapan Allah (Ef. 6:11). Lowe menjelaskanya demikian:

"Paul does not exhort the ephesian Church to lounch an offensive against Satan; he urges the merely to stand firm in the face of attck. Four times in this paragraph, he exhorts them to hold their ground. "put on the full armour ofr God in order that you may be able to stand: (6: 11)' "take up full armour of God, so that you may be able to with-stand ... and having accomplished everything, to stand (6; 13); stand then" (6: 14)., 42

Dengan demikian, sumber kemenangan dalam peprangan rohani di sini bukanlah pada tindakan menyerang, namun justru pada sikap yang bergantung penuh kepada kuasa Allah. Gagasan tentang bertahan ini juga terdapat dalam beberapa ayat yang mengungkapakan keberadaan senjata rohani yang dipakai oleh umat Kristen. Paulus menyebutkan dalam Efesus

${ }^{41}$ Ibid, 35.

${ }^{42}$ Ibid, 61-62. 
6:14-17, yang meliputi ikat pinggang kebenaran, baju zirah keadilan, kasut kerelaan, perisai iman, ketopong keselamatan dan pedang Roh, yaitu firman Allah. Semua peralatan tersebut merupakan perlengkapan untuk bertahan. Satu-satunya alat untuk menyerang adalah pedang roh. Namun pedang di dalam konteks ayat ini pun bukanlah pedang panjang untuk keperluan menyerang, melainkan pedang pendek yang biasa digunakan dalam keadaan terjepit dan terdesak untuk mempertahankan diri.

Dari telaah terhadap ayat-ayat yang dikemukan Wagner untuk mendukung hipotesanya, dapat ditarik kesimpulan sebagai berikut: Wagner benar, dalam komentarnya tentang keberadaan tentang roh-roh jahat sebagai musuh orang-orang Kristen. Namun, pernyataan Wagner mengenai detil tingkatan roh-roh tersebut, nampaknya tidak mendapatkan dukungan dari teks-teks yang ia telah paparkan. Konsep peperangan rohani yang menyerang dalam benak wagner pun tidak dapat disahkan dengan ayat-ayat tersebut. Wagner telah terburu-buru menilai setiap data hanya pada level permukaan saja, di mana teks-teks tersebut seolah-oleah berbicara mengenai keberadaan roh-roh teritorial. Konsekuensi daripada cara ini pasti mengakibatkan teks-teks Alkitab tidak berbicara apa adanya. Dengan kata lain temuan Wagner sebenarnya bukan makna mula-mula yang dimaksud oleh penulis Alkitab. Dengan demikian, gagasan roh-roh territorial yang dikembangkan oleh Wagner tidak bisa dipertanggungjawabkan secara hermeneutik. Sebaliknya, proses intepretasi teks yang dikembangkan oleh wagner dapat dinilai sebagai usaha eisogesis, ketimbang eksegesis.

\section{Relevansi dalam Pelayanan Pastoral}

Walaupun pandangan Wagner tentang roh-roh teritorial kontroversial dalam berbagai bidang, namun kita tidak dapat mengabaikannya begitu saja. Faktanya, pandangan ini justru diterima dan dipraktikkan di banyak gereja di Indonesia; secara khusus gereja tertentu yang beraliran Pentakosta-Kharismatik . Ada beberap hal yang menyebabkan pandangan ini dapat diterima secara luas: pertama, pandangan roh-roh teritorial oleh Wagner dikemas dalam pengajaran yang pragmatis, yang menjanjikan hasil yang menarik khususnya bagi gereja yang ingin mengalami pertumbuhan. Wagner telah menyumbangkan gagasan yang menyuguhkan jalan pintas untuk mencapai perkembangan gereja. Dia menjanjikan bahwa apabila gereja mampu memerangi kuasa-kuasa roh teritorial, maka otomatis gereja akan bertumbuh dengan baik. Pandangan Wagner yang pragamatis ini menjadi jalan pintas yang menjanjikan, ketimbang teori teologi misi yang susah dicerna oleh jemaat awam. Kedua, bangkitnya semangat kaum awam untuk terlibat dalam pelayanan. Mereka adalah orang-orang yang ingin terlibat dalam pelayanan, namun pad saat yang bersamaan tidak memiliki bekal pemahaman Alkitab yang memadai. Hal yang seringkali terjadi adalah mereka berupaya belajar secara pribadi dengan memanfaatkan buku-buku rohani yang ada. Biasanya minat komsumsi mereka 148 | Copyright@ 2020, CARAKA, ISSN 2722-1407 (Cetak), 2722-1393 (Online) 
terhadap bacaan kristen adalah buku-buku yang populer. Tidak dapat disangkal bahwa bukubuku karangan $\mathrm{C}$. Peter Wagner tentang roh-roh teritorial dan peperangan rohani merupakan buku-buku yang terjual laris. Tidak pelak lagi, akhirnya buku-buku tersebut menjadi komsumsi mereka yang berhasrat mendapat bekal pelayanan. Sensor pengajaran yang memadai tidak mengimbangi pembacaan buku ini, sehingga jemaat awam akan menelan konsep-konsep di dalamnya apa adanya. Ketiga, menyangkut pandangan hidup masyarakat Indonesia itu sendiri. Masyarakat indonesia pada umumnya adalah masyarakat yang memiliki latar belakang anismisme dan dinamisme yang mempercayai keberadaan roh-roh yang mendiami tempat tertentu. Istilah-sitilah seperti penunggu, dayangan, penguasa, dll, merupakan sebutan terhadap roh-roh yang menguasai teritorial tertentu. Dengan demikian, tidak dapat dipungkiri bahwa ajaran roh-roh teritorial pada akhirnya mendarat mulus dalam pemahaman orang-orang kristen di Indonesia, yang notabene dulunya juga memiliki latar belakang tersebut.

Meluasnya pandangan roh-roh teritorial dalam pandangan jemaat tentunya tidak dapat dipungkiri. Namun, apakah karena pandangan ini menjadi trend yang populer, akhirnya kita mengadopsinya begitu saja tanpa ada usaha memberi verifikasi dan klarifikasi yang baik kepada jemaat yang kita layani. Ataukah sebaliknya kita segera memberi label sesat dan mengingatkan jemaat dengan keras untuk menolak pandangan tersebut. Secara teoritis mungkin hal tersebut masuk akal, namun dalam tataran praktis langkah tersebut justru kontraproduktif. Lebih lanjut, meluasnya penerimaan tersebut sebenarnya mengetengahkan tantangan bagi gereja supaya mampu merancang suatu program pendidikan gereja yang Alkitabiah namun juga dapat diterima secara praktis

Program pengajaran yang diberikan berkaitan dengan roh-roh tertorial seharusnya memuat beberapa pertimbangan berikut: pertama, pandangan tentang roh-roh tertorial harus ditempatkan pada wawasan peperangan rohani yang berimbang. Artinya jemaat harus memahami bahwa peprangan rohani sebenarnya merupakan realita kehidupan yang di dalmnya jemaat tidak hanya berperang melawan kuasa gelap, namun juga tatanan sosial dunia yang rusak dan kelemahannya sebagai manuisa. Peperangan seharusnya juga melibatkan sisi kedagingan manusia dan struktur dunia yang berdosa. Clinton E. Arnold mengungkap fakta ini demikian,

"Kita hidup di dalam jaman di mana jaman Ini (sebutan bagi jaman yang dikuasai Iblis) berada dalam posisi yang tumpang tindih dengan jaman yang akan datang (jaman Kerajaan Allah). Konsekuensi langsung dari "overlapping" dua jaman ini adalah bahwa kita memasuki jaman yang diwarnai dengan "ketegangan" (tension) dan pergumulan atau konflik di antara kekuatan-kekuatan kegelapan dan kekuatan terang. Berita baiknya adalah bahwa bagian yang paling menentukan dalam peperangan ini telah dituntaskan di Golgota. Peristiwa Golgota telah membuat Iblis dan sekutunya pada posisi yang tak mungkin menang. Kekalahan total hanya masalah waktu. 
Peperangan Rohani: Milik Siapa? Ada tendensi bagi beberapa orang untuk memandang peperangan rohani sebagai bentuk khusus dari pelayanan Kristen.

Pemahaman yang lebih tepat adalah bahwa peperangan rohani adalah sebuah gambaran umum dari pergumulan semua orang Kristen yang hidup di antara dau jaman yang tumpang tindih tersebut. Jadi pada dasarnya peperangan rohani itu cukup luas cakupannya. Ia menyentuh semua area dari kehidupan keluarga, hubungan-hubungan kita, gereja kita, tetangga kita, komunitas kita, dan tempat pekerjaan kita."43

Wagner terlau berlebihan mengkaitkan semua persoalan dengan peperangan rohani, sehingga hal tersebut mengakibatkan ia cenderung memahami semua hal dari sudut peperangan. Pandangan Wagner yang menekankan hanya pada satu sisi dan mengabaikan sisi-sisi lain ini akhirnya membuat teorinya timpang. Pada tataran praktis, pemikiran semacam ini akan cenderung membawa para jemaat awam mengukur segala sesuatu hanya dari sudut rohani semata. Peperangan rohani terhadap roh-roh tertorial pada akhirnya akan dipahami sebagai sarana yang paling efektif dan sekaligus jalan pintas untuk mempercepat pertumbuhan gereja. Pada saat yang sama faktor-faktor lain seperti manajemen gereja, pemuridan. Penginjilan dan penatalayanan akhirnya diabaikan

Kedua, pelayanan peperangan rohani tidak boleh di tempatkan sebagai pelayanan khusus yang tempatnya lebih istimewa ketimbang pelayanan yang lain. Dengan demikian, jemaat tidak menganggapnya sebagai suatu pelayanan yang mengharuskan kualifikasi khusus dan hanya dapat dilakukan orang-orang tertentu. Ketiga, jemaat harus diajar bahwa peperangan rohani bukanlah satu-satunya kunci efektif bagi pertumbuhan gereja. Ada banyak faktor lain yang menunjang pertumbuhan gereja yang memerlukan keterlibatan jemaat. Keempat, jemaat harus diajar mengerti bahwa tindakan mengidentifikasi pandangan roh-roh terorial sebenarnya tidak memiliki dasar Alkitabiah. Di satu sisi, kita menerima bahwa keberadaan roh-roh tertorial memang ada, namun tindakan untuk mengidentifikasi dengan pemetaan dan doa peperangan keliling, sebenarnya bukan anjuran Alkitab.

\section{KESIMPULAN}

Pandangan C. Peter Wagner tentang Roh-roh teritorial mengemukakan bahwa kunci mempercepat penginjilan dunia adalah penghancuran kuasa roh-roh territorial melalui peperangan rohani. Gagasan Wagner ini menjanjikan hasil yang menarik, khususnya bagi gereja yang ingin mengalami pertumbuhan. Namun bila diuji dengan teliti, gagasan tersebut sebenarnya menunjukkan "cacat pemikiran" yang memberatkannya untuk diterima sebagai pemikiran yang Alkitabiah. Pertama, apakah benar bahwa satu-satunya kunci efektif bagi pertumbuhan gereja itu adalah peperangan rohani terhadap roh-roh teritorial? Alkitab tidak pernah mengatakan demikian dan faktanya ada banyak faktor lain yang menunjang

${ }^{43}$ Clinton E Arnold, 3 Crucial Questions About Spiritual Walfare (Grand Rapids Michigan: Baker Book House, 1997), 42. 
pertumbuhan gereja yang memerlukan keterlibatan jemaat. Kedua, harus diakui bahwa keberadaan roh-roh tertorial itu memang ada, tetapi tindakan mengidentifikasi dengan pemetaan dan doa peperangan keliling sebenarnya bukan ajaran dan anjuran Alkitab. Ketiga, gagasan roh-roh tertorial Wagner ini disajikan dalam wawasan peperangan rohani yang tidak seimbang. Peperangan rohani pada hakikatnya adalah realita kehidupan yang di dalamnya tidak hanya berperang melawan "kuasa gelap", namun juga tatanan sosial dunia yang rusak dan kelemahannya sebagai manusa. Keeempat, gagasan roh-roh teritorial ini telah memunculkan pelayanan peperangan rohani tingkat startegis yang memerlukan kualifikasi khusus yang posisinya lebih istimewa ketimbang pelayanan yang lain dan oleh karenanya hanya dapat dilakukan oleh orang-orang tertentu dengan kulifikasi khusus. Konsep ini tentunya tidak bisa dibenarkan secara ajaran Alkitab dan tidak relevan dengan pemberdayaan jemaat yang juga merupakan penunjang keberhasilan pemberitaan Injil.

\section{DAFTAR PUSTAKA}

Arnold, Clinton E. 3 Crucial Questions About Spiritual Walfare. Grand Rapids Michigan: Baker Book House, 1997.

Budi, Ferry Setiawan. "Meningkatkan Pertumbuhan Gereja Melalui Penerapan Strategi Peperangan Rohani." REDOMINATE: Jurnal Teologi dan Pendidikan Kristiani 1, no. 1 (December 2019): 49-75.

Geisler, Norman. Christian Apologetics. Grand Rapids Michigan: Baker Book House, 1976. Hamzah, Amir. Metode Penelitian Kepustakaan: Kajian Filosofis, Teoritis, Dan Aplikatif. Batu: Literasi Nusantara, 2018.

- Metode Penelitian Kualitatif: Rekontruksi Pemikiran Dasar Serta Contoh Penerapan Pada Ilmu Pendidikan, Sosial Dan Humaniora. Batu: Literasi Nusantara, 2018.

Lowe, Chuck. Territorial Spirits and World Evangelisation? Great Britain: OMF International, 2000.

Soerono. “Telaah Kritis Terhadap Konsep Doa Peperangan Rohani Tingkat Strategis Menurut Peter Wagner." Veritas: Jurnal Teologi dan Pelayanan 7, no. 1 (2006): 101-104.

Sutanto, Hasan. Hermeneutik: Prinsip Dan Metode Penafsiran Alkitab. Malang: SAAT, 2007. Wagner, C Peter. Berdoa Dengan Penuh Kuasa: Cara-Cara Berdoa Yang Efektif Dan Mendengar Suara Tuhan Dengan Jelas. Jakarta: Nafiri Gabriel, 1997.

- Doa Peperangan: Strategi Untuk Bertempur Melawan Penguasa Kegelapan. Jakarta: Metanoia, 1994.

- Roh-Roh Teritorial: Wawasan Terhadap Tingkat Strategis Peperangan Rohani Dari Sembilan Belas Pemimpin Kristen. Jakarta: Immanuel, 1994.

Wagner, C Peter, and F Douglas Pennover. Adu Kuasa Dengan Penghulu Kegelapan. Bandung: Yayasan Kalam Hidup, 1990. 